\title{
COMMENTS ON OIL AND GAS JURISPRUDENCE IN CANADA AND THE UNITED STATES
}

\author{
HOWARD R. WILLIAMS*
}

The writer was privileged to serve as commentator at the Fourth Annual Research Seminar in Oil and Gas Law sponsored by the Canadian Petroleum Law Foundation. Each member of the Seminar group having participated in the preparation of one of the papers presented by a spokesman in brief oral summary, discussion was pointed and informative. The papers collected in this volume having been revised, the writer's comments will merely direct attention to several topics touched upon, without attempting to summarize all of the actual discussion.

1. Strict construction of oil and gas

leases in favor of lessors.

A matter alluded to in several papers and in much of the discussion of Gunderson, ${ }^{1}$ Gibbard, ${ }^{2}$ Kininmonth, ${ }^{3}$ and Kanstrup ${ }^{4}$ cases was the policy of strict construction of oil and gas leases in favor of lessors. It was noted that this construction policy differs from that applicable to ordinary commercial transactions and from that applicable to other conveyances of interests in land.

In this regard, the courts of Canada are following the beaten path well-trod by the courts in the States. ${ }^{5}$ This phenomenon may be due in part to the fact that the earliest cases presented to the courts of a state or province after the first production of oil and gas generally involve allegations that innocent landowners, ignorant of the practices of and the instruments customarily employed by the industry, have been defrauded or cheated by lease hounds or other persons with special knowledge of these matters. The poor farmer, scarcely able to read the instruments presented for his signature after a hard-sell by a persuasive pitch man, signs what is described to him as a lease in ordinary form-and it turns out to be a conveyance of minerals or a perpetual royalty deed. When the first oil and gas cases presented to a court are of this character, it is not entirely surprising that the court is led to construe the instruments executed by the farmer rather strictly, in favor of the lessor. Quickly there develops a constructional policy based on the protection of "the poor, ignorant, illiterate farmer" against the sharp practices of the lease hound. Thus, one can anticipate the result of most cases involving construction of oil and gas leases by reciting the phrase, "we construe in favor of the poor, ignorant, illiterate farmer."

It appears to matter little that the "poor, ignorant, illiterate farmer" may be a well-educated owner of thousands of acres; thus in a brief prepared in a Nebraska case involving the question whether a lease covering

- Professor of Law, Stanford University.

1 Shell Oil Co. v. Gunderson, [1960] S.C.R. 424, 23 D.L.R. $2 d 81$ (1960).

2 Shell Oil Co. v. Gibbard, [1961] S.C.R. 725, 36 W.W.R. 529, 30 D.L.R. 2d 386 (1961).

8 Canada-Cities Service Petroleum Co. v. Kininmonth, [1964] S.C.R. 439, 47 W.W.R. 437, 45 D.L.R. 2d 36 (1964).

4 Canadian Superior Oil of California Ltd. v. Kanstrup, [1964] S.C.R., 49 W.W.R. 257, 47 D.L.R. 2d 1 (1964)

s See 3 Williams, Oil and Gas Law, \& 628 (1962). 
some 22,000 acres of land had expired by reason of failure to make timely payment of rentals, counsel urged that "It should be remembered that Appellant is an experienced oil operator, and that [lessors] are sandhills ranchers." It does not appear to matter that the real parties in interest are (as is frequently the case) two oil companies, the second of which owns a top lease, the validity of which depends upon the termination of the prior lease by strict construction thereof; again we construe in favor of the poor, ignorant, illiterate farmer-viz., the top lessee in this instance. In Canada the same construction policy is followed although the "poor, ignorant, illiterate farmer" may be the Crown.

One would hope that the courts of Canada would not find it necessary to follow the strict construction policy which has developed in the States. Rules of construction applicable to ordinary commercial instruments would appear more appropriate today than rules designed to protect the poor, ignorant, illiterate farmer from the machinations of the city slicker. Unfortunately, however, at this stage the strict construction policy seems to be in the ascendency in Canada as in the States.

In thus inveighing against the policy of strict construction of oil and gas leases, I would not be understood as indicating a preference for a change in the construction of limitation provisions of the lease. As is well known, the typical oil and gas lease is construed as including limitation provisions in the habendum and rental clauses. One may perhaps wonder why lease draftsmen elect to include limitation provisions rather than conditions, but for some years this has been the practice. So long as language of limitation rather than language of condition is utilized, it appears appropriate to continue application of the rule that equitable considerations are irrelevant to the operation of a clause of limitation.

A draftsman may, of course, modify the operation of a limitation provision by appropriate language in the instrument. Thus the limitation provision of the delay rental clause has been modified in some instances by the inclusion of a clause relating to good faith attempt to pay rentals. ${ }^{\circ}$ There is little case authority on the operative effect of this clause but such as there is sustains it as against the claim that it is repugnant to the rental clause. Likewise various savings clauses in the lease (e.g., shut-in royalty clause, drilling operations clause, dry hole clause) in effect are modifications of the limitation provision of the habendum clause; the validity of these provisions has been uniformly sustained.

\section{Utilization in Canada of case authority from the States.}

In reading the papers prepared for this Seminar, the writer noted a heavy use of cases reported in the Pacific Reporter, a phenomenon previously noted in the opinions of Canadian courts and Canadian periodical literature on oil and gas. It is almost as if Canadian lawyers have access to no Reporter from the States other than the Pacific Reporter. Could this be due to the proximity of certain Pacific Reporter jurisdictions to the western provinces? Or is it due to the fact that Oklahoma and California, two Pacific Reporter states, view the lease as creating a profit à prendre as does Canada?

B Id. at 8605.6, at note calls $12-14 ; 4$ Id. at 682.1 . 
The rather arbitrary boundary lines drawn by the West Publishing Company for its Reporter system have almost as much influence on the development of jurisprudence in the States as the state boundary lines themselves. No doubt this is due to the fact that a lawyer frequently acquires for his library the Reporter which includes the cases of his own jurisdiction, thereby acquiring the cases reported by courts of other jurisdictions in the same Reporter; only larger libraries include all of the Reporters and hence many lawyers have ready access only to cases reported in one Reporter. Thus it is that there is more migration of jurisprudence from state to state within a Reporter than from state to state across Reporter boundaries.

Since 1952 the Oil and Gas Reporter, edited by the Southwestern Legal Foundation and published by Matthew Bender \& Co., has brought together in a single Reporter most of the cases, federal and state, dealing with the law of oil and gas. It has seemed to this observer that the availability of this Reporter has increased the utilization by courts of one state of cases from other states in oil and gas matters. Oil and gas jurisprudence has become more migratory as a result of this publication.

In the search by Canadian lawyers and courts for precedent from the states, attention should be given to decisions of courts of states not included in the Pacific Reporter. In particular, for several reasons, attention should be given to cases from Texas. That state has had greater production of oil and gas than others and there have been many more cases decided. Moreover, the Supreme Court and certain of the intermediate appellate courts of Texas over the past fifty years have included a number of able jurists who have brought to the decision process an understanding of the oil and gas industry and of its legal problems. And perhaps most important of all, the Texas oil and gas jurisprudence had the benefit of the relatively early series of articles in the Texas Law Review written by A. W. Walker, Jr. on the nature of the interests created by the oil and gas lease. This series in the late 20's and early 30's provided the courts and lawyers with a reasoned structure for the development of oil and gas jurisprudence.

Canadian courts and lawyers appear to have taken the view in the use of authority from the States that (to paraphrase Orwell's The Animal Farm) "all states are equal but some are more equal than others"; and the more equal states in their view have been those included by the West Publishing Co. in the Pacific Reporter system. The writer would agree that some states are more equal than others but that California (a Pacific Reporter jurisdiction whose cases are frequently cited in Canada) is not one of the "more equal" inasmuch as its oil and gas jurisprudence has not as yet worked its way out of the confused condition which prevailed at least until around 1950; on the other hand, for the reasons mentioned above, Texas should be viewed as one of the "more equal" and careful attention should be given by Canadian courts and lawyers to case authority from that state. In the formative stages of the oil and gas jurisprudence of Mississippi, the courts of that state made it plain that "as to the law of oil and gas, Mississippi, as a newcomer, *** aligned itself

7 Walker, The Nature of the Property Interests Created by an Oil and Gas Lease in Texas, 7 Tex. L. Rev. 1 (1928), 7 Id. 539 (1929), 8 Id. 483 (1930), 10 Id. 291 (1932), 11 Id. 399 (1933). 
with Texas;"8 this is a policy worthy of emulation. There are elements of Texas jurisprudence (e.g., strict construction of oil and gas leases in favor of the poor, ignorant, illiterate farmer) which I would not urge upon Canadian courts, and hence "alignment" of Canadian and Texas jurisprudence is not called for; nonetheless Canadian lawyers and courts would profit from a careful examination of and careful selection from Texas decisional authority on matters of oil and gas law.

The Seminar discussions indicated that there was some misunderstanding by Canadian lawyers concerning the relative importance of federal and state court decisions in the States on oil and gas matters. Of fundamental importance in this connection is an appreciation of the differences in the two federal systems, that of Canada and of the United States. On matters of tort, contract and property law where there are no federal questions involved, the highest court of the state is the ultimate authority. Although many of the important oil and gas decisions issue from federal courts which may have jurisdiction by reason of diversity of citizenship of the litigants, such federal court decisions are based in theory on an application of the law of the state in which the land in question is located. This is not to say, of course, that federal courts never make new oil and gas law; some such courts have played a significant role in the development of oil and gas jurisprudence. ${ }^{9}$ But in the end, if the state court differs from the position taken by a federal court, the view taken by the state court prevails. Thus a Canadian lawyer should not view an opinion by the federal Court of Appeals for the Tenth Circuit as more authoritative than a decision by the Supreme Court of Texas or the Supreme Court of Arkansas; for that matter the opinion of that federal court in a case arising from Oklahoma is not as authoritative as an opinion of the Supreme Court of Oklahoma on a matter of Oklahoma oil and gas jurisprudence since the federal court is required to apply the Oklahoma law and the Supreme Court of Oklahoma is the highest authority on that subject.

\section{View that the oil and gas lease}

creates a profit d̀ prendre.

Canadian courts, as have the courts of California and Oklahoma, have viewed the interest created by an oil and gas lease as a profit à prendre. Many of the States, on the other hand, have viewed the lessee's interest as corporeal rather than incorporeal in character. Whichever view is adopted as to the nature of the lessee's interest, excessive conceptualism can have unfortunate consequences. In the States, the courts have generally passed through the conceptual period, and now the classification of the interest of the lessee as corporeal or incorporeal in character has little if any practical significance. ${ }^{10}$ The Canadian courts, as viewed by this observer, continue to be unduly conceptual. The ancient seaweed cases, the basis for much of the lore concerning the profit à prendre, have little if any relevance to the interests created by instruments dealing with the exploration, development and production of immensely important natural resources today. If any of this ancient lore is to be applied to the oil and

8 Per Hutcheson, C.J., in Berry v. Tide Water Associated Oil Co., 188 F. $2 d$ 820, at 822 (5th Cir. 1951).

- See Williams, The Role of Federal Courts in Diversity Cases Involving Mineral Resources, 13 Kansas L. Rev. 375 (1965); Recent Developments in Oil and Gas Law, A.B.A., 1964 Proceedings of Section of Mineral and Natural Resources Law 22, at 29 (1964).

10 See 1 Williams and Meyers, Oil and Gas Law, \& 211 (1959). 
gas lease, it should be applied selectively rather than blindly. What is really involved is the construction of a commercial instrument more closely related to one dealing with the erection and operation of a great manufacturing plant than to an agreement permitting a person to go upon the land of another to sever and remove seaweed to be utilized as fertilizer. The profit à prendre lore dealing with such matters as divisibility of the profit, surcharges of the profit, and abandonment of the profit are totally irrelevant to the oil and gas lease.

\section{The operative effect of a top lease.}

In the discussion of the Potapchuk case, it was readily apparent that some Seminar participants viewed top leasing as fundamentally nefarious in character. To borrow the language of Bramwell, L.J. quoted in the paper written by W. H. Hurlburt, the top lessee was viewed as a caput lupinum.

This attitude was somewhat surprising. What is wrong in a conveyance by a lessor of any part of his retained interest under an oil and gas lease? He may convey a fraction of his royalty under the lease; he may convey a perpetual royalty; he may convey the land subject to the lease. What is basically unfair or improper in his conveyance of a portion of his reversionary interest?

If the lessor conveys his entire interest in the leased premises, clearly he does not have the right thereafter to affect the interest of his grantee by modifying the original lease. If modification is sought by the lessee, it must be sought from the transferee of the lessor. So also, if the lessor executes a top lease, in effect he has conveyed a portion of his reversionary interest to the top lessee; and if modification of the first lease is sought by the lessee, he must seek it from the top lessee.

5. Obligations of the lessee under express and

implied drilling covenants of oil and gas leases.

Many early lease forms contained no reference to the obligations of the lessee as concerns the drilling of an initial exploratory well, the drilling of development or the drilling of protection wells. The courts in the States, under such circumstances, implied certain obligations of the lessee as concerns exploration, development and protection. The response of lease draftsmen in some instances was to include express covenants on these matters and as a consequence we have in the States forms which are silent on these matters, forms which deal with some of these matters, and forms which purport to deal with all of such matters.

Perhaps the major reason for express treatment of the covenant obligation is the lessee's desire for certainty in the matter. Generally speaking, an express covenant on a particular matter excludes the implication of a covenant on the same matter and the lessee may be able to avoid dispute with his lessor if he can point to specific language of the lease instrument as specifying the nature and character of his duty.

Canadian lease forms appear generally to take a middle course on this matter, viz., they contain express provisions on some but not all of the matters which are the subject of implied covenants in the States. Typical-

11 Pan American Petroleum Corp. V. Potapchuk and Scurry-Rainbow Oits Ltd., 46 W.W.R. 237 (Supreme Court of Alberta 1964), appeal dism'd (Supreme Court of Alberta, App. Div., 1964) [unreported], (Supreme Court of Canada, May 11, 1965) [unreported]. 
ly they contain an "unless" type drilling and rental clause, thereby negating the implication of a covenant to drill an initial exploratory well. Many contain an express offset covenant, and this covenant, if reasonable, should prevent the implication of a covenant on that subject. Absent from most lease forms are covenants relating to development and further exploration, and hence it seems probable that Canadian courts will in time be led to find implied obligations of the lessee in these connections.

One word of caution should be uttered concerning the effect on implied covenants of express lease provisions. Generally speaking, an express lease provision on a particular topic will prevent the implication of a covenant on the matter. Thus, ordinarily an express offset covenant of the lease will prevent the implication of an offset obligation of a different character. But the express provision will negate only a covenant dealing with the same particular topic. Thus the drilling and rental provision of the lease will be read as negating any implied covenant to drill an initial exploratory well, but in several states it will not negate the obligation to drill an offset well even though that is the initial well. An express offset covenant will not prevent the implication of a development covenant; nor will express development provisions of the lease negate the implication of a further exploration covenant. ${ }^{12}$

\section{Economic return from Crown leases.}

It was somewhat surprising for this observer to learn that in practice Crown lands are leased on the basis of the greatest bonus offered for a lease providing for a fixed sliding-scale royalty which in fact realizes for the Crown something less than one-eighth. This method realizes rather substantial moneys, no doubt, but in view of the quantity of Crown-owned minerals, one is led to ask whether the public interests might not be better served by emphasis on larger royalties and smaller bonus; perhaps it would be to the interest of both parties to the leasing transaction to bargain for a net profits or other such interest in production rather than a bonus. This probably would realize more in the long run from Crown lands and yet be more attractive to lessees inasmuch as their capital investment in the form of bouns would be greatly reduced. A study of the California experience in leasing certain state-owned minerals might be of value.

It may be urged, of course, that the bonus-royalty scheme now employed gives the Crown the maximum benefit of the bargain inasmuch as the rights of the Crown lessee are subject to variation from time to time by unilateral regulatory action by the lessor, the Crown. This is a matter somewhat difficult for a person from the States to understand, for we view the sovereign as simply another lessor, bound by the terms of the lease contract and with extremely limited power to effect unilateral changes in the contract by regulation. In the light of Professor A. R. Thompson's interesting paper on the topic prepared for the Seminar, one is led to ask whether provision for unilateral change of the rights of the Crown in the royalty return from leases has practical significance. Presumably there are substantial political problems involved which limit such unilateral variation of the rights of the Crown. Moreover, Professor

12 See 5 Williams and Meyers, Oil and Gas Law 858 807, 826-826.3, 835-835.3, 846, 858-858.3 (1964). 
Thompson's discussion of the doctrine of "core of the contract" is persuasive that "certain fundamental terms of the lease ... would not be alterable at the will of the Crown by incorporation of statutory provisions or regulations." In other words, both by reason of political responsibility and by reason of legal safeguards, the rights of the lessee may be protected. Assuming this to be so, it might be desirable for the Crown to bargain for a greater economic return from production by Crown lessees, even at the cost of smaller return from bonus payments. In a sense, the Crown would then bear a greater share of the risk (viz., it would give up the larger bonus for a larger economic return from production); this riskbearing role would probably be economically profitable to the Crown.

\section{A look at the future of the lease.}

Much of the discussion at the Fourth Annual Research Seminar of the Canadian Petroleum Law Foundation, as in other Institutes in Canada and the States over the years, was concerned with problems posed for draftsmen of instruments and for operators by judicial construction of particular lease clauses. One of the pecularities of the oil and gas industry is that there is no standard lease form. True, in the States most leases bear, in one form or another, the label "88 lease", but this label tells us little more than that the lease probably has an "unless" type drilling and rental clause. Perhaps at this late date it is futile to hope for standardization of lease forms. Nonetheless, let this paper close with the expression of hope that such an organization as the Canadian Petroleum Law Foundation will undertake to formulate a "standard" form, fair to lessor and lessee. One might hope that the day would come when oil and gas leases (and perhaps other documents commonly utilized in the industry) will be brief instruments containing identification of the parties, words of grant, description of the premises, a clause incorporating by reference the provisions of the standard form, and perhaps a clause or two designed to modify particular provisions of the standard form. If this could be done, the parties and their attorneys could give primary attention to the latter few clauses which, by reason of special circumstances, modify the standard provisions of the instrument in question. I suggest that this is a worthwhile project of the Foundation; for a number of reasons, including the large acreage controlled by a limited number of lessors, you in Canada are in a better position than we in the States to undertake such a project. Your efforts would be watched with great interest and no doubt such success as might be attained in this enterprise would be of great benefit, both north and south of our common border. 